\title{
Selection For Resistance and Tolerance to Oat Mosaic Virus and Oat Golden Stripe Virus in Hexaploid Oats
}

\author{
Scott L. Walker, Graduate Research Assistant; Steven Leath, USDA-ARS and Associate Professor, Department of \\ Plant Pathology; J. Paul Murphy, Professor, Department of Crop Science; and Steven A. Lommel, Professor, De- \\ partment of Plant Pathology, North Carolina State University, Raleigh 27695-7616
}

\begin{abstract}
Walker, S. L., Leath, S., Murphy, J. P., and Lommel, S. A. 1998. Selection for resistance and tolerance to oat mosaic virus and oat golden stripe virus in hexaploid oats. Plant Dis. 82:423427.

Coker 716, a hexaploid oat cultivar resistant to both oat mosaic virus (OMV) and oat golden stripe virus (OGSV) was crossed to three susceptible cultivars (Brooks, Madison, and Tech) to form three individual populations. Individual breeding lines were derived from each cross in the $\mathrm{F}_{2}$ generation and tested in plots consisting of equally spaced individual hills in OMV- and OGSV-infested soils and non-infested soils to evaluate resistance and yield loss of individual lines. Foliar symptoms, harvest index, and yield loss were examined as selection criteria for resistant genotypes. The study was conducted over 2 years at two North Carolina locations that differed in soil type and climate. Multiple regression models describing yield loss in each cross due to rating, year, and location were calculated. Coefficients of multiple determination in these models ranged from 0.39 to 0.51 . Yield loss ranged from 39 to $60 \%$ among different crosses. Infection by OMV and OGSV accounted for the majority of yield loss in two of the populations. Disease severity varied widely over years and locations. The results suggest that selection of lines with symptomatic tissue of $10 \%$ or less, or selection of tolerant lines, is needed for breeding progress.
\end{abstract}

Additional keywords: multiple regression model, soil-borne virus

Oat mosaic virus (OMV) and oat golden stripe virus (OGSV) are both vectored by the slime mold Polymyxa graminis and have the potential to cause significant damage to winter oat (Avena sativa L.) crops when environmental conditions are favorable. Initial infection of OMV and OGSV occurs in the roots of Avena spp. through penetration by $P$. graminis zoospores which contain the viruses $(1,6,8,13,17)$. Infection occurs in the fall whenever free water is available for dissemination of the fungal zoospores. The viruses enter the host plant and remain dormant through the winter. In spring, mosaic patterns characteristic of OMV occur in leaves and shoots, and may be followed a few weeks later by the bright yellow striping associated with OGSV. Both viruses are highly sensitive to temperature and foliar symptoms quickly disappear with increasing temperature $(3,19)$. After foliar symptoms disappear, stunting and yield loss are the only remaining indi-

Corresponding author: Steven Leath

E-mail: steven_leath@ncsu.edu

Accepted for publication 6 January 1998.

Publication no. D-1998-0212-02R

This article is in the public domain and not copyrightable. It may be freely reprinted with customary crediting of the source. The American Phytopathological Society, 1998. cations of OMV and OGSV infection. Yield loss of $100 \%$ due to OMV infection was reported by McKinney (20) in 1949, when severely infected plants failed to set seed. Symptomatic plants may be infected with OMV or OGSV or a combination of both viruses, and infection will reoccur with successive oat crops (11). The fungal vector provides protection of OMV and OGSV against unfavorable environmental conditions and long rotations to non-host crops, and allows the viruses to persist almost indefinitely once a field has become infested $(15,17)$.

OMV and OGSV have been reported most frequently in the southeastern United States, but OMV has also been reported in Washington state, England, and Wales $(3,4,7,18)$. A virus similar to OGSV was reported in France (16).

The only effective means of controlling OMV and OGSV is the use of resistant cultivars. No species of Avena has been found to be immune to OMV and OGSV, and under high disease pressure even resistant cultivars can exhibit severe damage (21). Several studies have reported a range of phenotypes in different species and cultivars, indicating different levels of resistance $(3,12,18,21)$. In crosses of resistant $x$ susceptible oat cultivars, a range of resistance levels resembling a normalized curve are reported, indicating that resistance is not monogenic. However, most resistant cultivars trace back to a single source of resistance in the variety Fulghum. Fulghum was derived from a cross using $A$. byzantina, one of the most resistant Avena species (9). Heritability of resistance is high, with broad-sense heritability estimates ranging from 0.59 to $0.88(5,22)$. The high heritability of resistance indicates that few genes are involved; environmental influences may help to create continuous phenotypes in a population of oat breeding lines (22).

The exact mechanism of resistance to fungally vectored viruses is unknown, but two general possibilities exist: resistance to the vector and resistance to the viruses. There is some evidence for both mechanisms. Lapierre et al. (16) detected different levels of colonization by $P$. graminis in resistant and susceptible wheat cultivars infected by soilborne wheat mosaic virus (SBWMV). SBWMV has an etiology similar to OMV and OGSV. Both SBWMV and $P$. graminis have been detected in resistant plants (14). However, Himmel et al. (14) detected higher levels of SBWMV in the roots of susceptible cultivars than in roots of resistant cultivars during the winter dormant period. Himmel et al. hypothesized that the higher level of virus in the roots of susceptible cultivars created a larger reservoir of virus which moves into the shoots in spring.

The terms "tolerance" and "resistance" have been used interchangeably in previous literature regarding OMV (5). Byrd et al. referred to a reduced level of foliar symptoms as tolerance. In this study, we refer to a reduced level of foliar symptoms as resistance. Tolerance is defined as the ability of an oat line to produce higher-thanpredicted yields in relation to the level of foliar symptoms observed.

Selecting for resistance to OMV and OGSV can be difficult due to the transient nature of foliar symptoms and erratic spatial pattern of infection. Three criteria that can be used to evaluate resistance are severity of foliar symptoms, reduced level of plant biomass, and yield loss. In this study, we investigated these three criteria and evaluated their use for field testing of resistance to OMV and OGSV in oat.

\section{MATERIALS AND METHODS}

Coker 716, a hexaploid oat cultivar resistant to OMV and OGSV, was crossed to three susceptible oat cultivars: Brooks, Madison, and Tech. The three resulting 
half-sib populations (Coker $716 \times$ Brooks, Coker $716 \times$ Madison, and Coker $716 \times$ Tech), were advanced to the $F_{2}$ generation, and individual lines in the $\mathrm{F}_{3}$ generation were derived from each $\mathrm{F}_{2}$ plant. Generational advance was performed during the spring of 1993 in the greenhouse using sterilized potting soil. The Coker $716 \times$ Brooks population consisted of $46 \mathrm{~F}_{2: 3}$ lines; 67 and 77 lines were included in the Coker $716 \times$ Madison and Coker $716 \times$ Tech populations, respectively.

The $\mathrm{F}_{2: 3}$ lines derived from each cross were planted in both OMV- and OGSVinfested soil and non-infested soil at the Central Crops Research Station, Johnston County, North Carolina, and the Piedmont Crops Research Station, Rowan County, North Carolina, in fall 1993. Soil type at the Rowan location was a Hiwassee clay loam (clayey, kaolinitic, thermic, Rhodic Kanhapludult), while at the Johnston location the soil type was a sandy clay loam (clayey, kaolinitic, thermic, Typic Kanhapludult). Each station contains a field heavily infested with both OMV and OGSV. Replicated plots of each $\mathrm{F}_{2: 3}$ line from the three crosses were grown in the infested fields in 1994, and $F_{2: 4}$ lines were grown in 1995. As a control, each line also was grown simultaneously in non-infested plots of the appropriate soil types at each station. The position of the non-infested plots within each station was changed each year to reduce confounding effects on yield.

The experimental design was a splitsplit plot with two treatments (infested versus non-infested soil) as the main plot factor. Within each main plot, the three crosses functioned as the split plots. The split-split plots consisted of the $\mathrm{F}_{2: 3}$ and $\mathrm{F}_{2: 4}$ lines from each cross. Each line was replicated three times within each splitsplit plot. The lines were tested in hill plots consisting of 12 seeds from one line planted with a jab planter. Hill plots were spaced $24 \mathrm{~cm}$ apart in all directions. Two border rows of the susceptible parent Brooks were planted around the experimental lines in both the infested and noninfested treatments as a susceptible control. A resistant control was not included in this study, but previous research using these plots did include the resistant Coker 716 parent $(10,22)$. Each of the segregating populations produced lines with resistance similar to or exceeding the resistance data
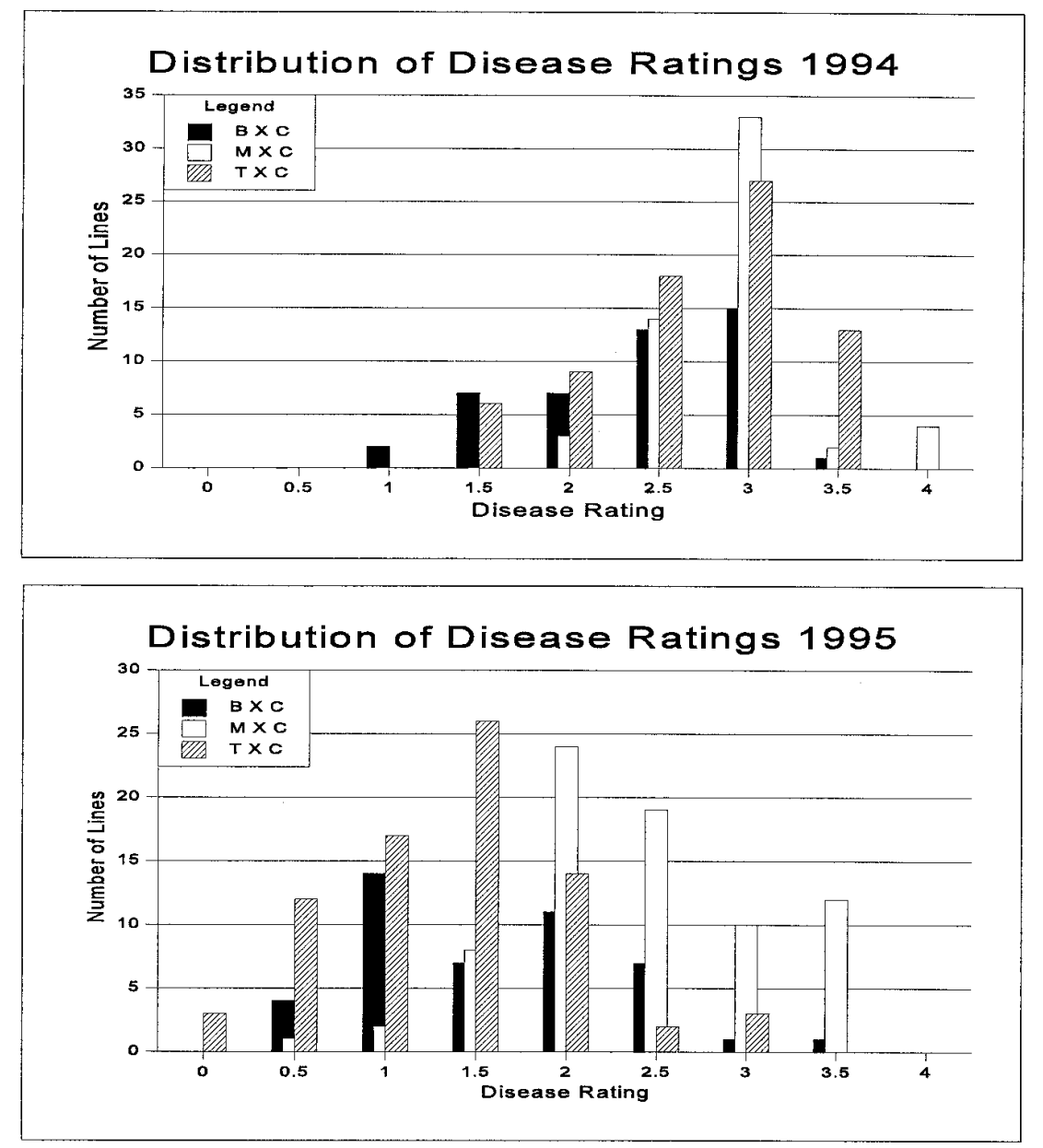

Fig. 1. Distributions of average disease ratings for symptoms of oat mosaic virus and oat golden stripe virus in individual lines for three test populations during the 1994 and 1995 field seasons. (B = Brooks, $\mathrm{C}=$ Coker 716, $\mathrm{M}=$ Madison, and $\mathrm{T}=$ Tech.) of Coker 716 in previous studies. The total number of hill plots tested was 4,680. Oats were planted in 1993 on 18 October in Johnston county and 4 November in Rowan county. Oats were planted in 1994 on 13 October in Johnston county and 17 October in Rowan county. Seed planted the second year were treated with Imidacloprid 480 (Gustafson Inc., Dallas, Texas) at a rate of 59.14 a.i. $\mathrm{ml} \mathrm{cwt}^{-1}$ for control of aphid transmission of barley yellow dwarf virus (BYDV). Fertilizer applications consisted of $73 \mathrm{~kg}$ hectare ${ }^{-1} 6-6-36(\mathrm{~N}-\mathrm{P}-\mathrm{K})$ on 14 October 1993 at Johnston, followed by $55 \mathrm{~kg}$ hectare $^{-1} 30-0-0$ on 18 February 1994. The Rowan location received $28 \mathrm{~kg}$ hectare $^{-1}$ ammonium nitrate (33 units N) on 4 October 1993, and two more applications of the same compound and rate on 18 February and 5 April 1994. Fertilizer was applied during the second field season on 12 October 1994 and top-dressed on 27 February 1995 at the Johnston location using the same compounds and rates as the first season. During the second season at Rowan, $28 \mathrm{~kg}$ hectare $^{-1}$ ammonium nitrate (33 units $\mathrm{N}$ ) was applied on 6 October 1994. On 27 February 1995, a top-dressing of $37 \mathrm{~kg}$ hectare ${ }^{-1}$ ammonium nitrate (35 units $\mathrm{N}$ ) was applied at Rowan, with a third application of $37 \mathrm{~kg}$ hectare ${ }^{-1}$ ammonium nitrate (20 units $\mathrm{N}$ ) performed on 15 March 1995. Malathion 57 EC (RhonePoulenc Ag. Co., Research Triangle Park, NC) was applied for control of cereal leaf beetle (Oulema melanopus L.) at a rate of 0.3 liters a.i. hectare ${ }^{-1}$ on 4 and 18 April 1994 and on 13 April and 9 May 1995 at the Rowan location. Malathion was applied at an identical rate during the first field season on 10 April 1994 at the Johnston location, but was not applied the second year due to low infestation of cereal leaf beetle at this location. Weeds were controlled by hand removal during both seasons at both locations.

Each hill plot was rated on a 5-point scale for symptoms of OMV and OGSV infection, where 0 indicated no symptoms; 1 indicated $<10 \%$ of all of the tissue in the hill plot was symptomatic; 2 indicated 10 to $25 \%$ symptomatic; 3 indicated 26 to $50 \%$ of the plot symptomatic; and 4 indicated $>50 \%$ of the hill plot plants symptomatic with reduced biomass. Symptoms of OMV and OGSV infection first occurred in early April at both locations and were scorable for 2 to 3 weeks. Single ratings for the combined symptoms of both viruses were recorded for each hill plot. Ratings of symptoms of OMV and OGSV were taken on 16 and 22 April at the Johnston location and on 14 and 20 April 1994 at the Rowan location. Second-year ratings were recorded on 16 and 21 March and 3 April 1995 at the Rowan location. Ratings were recorded on 17 and 24 March and 3 April 1995 at the Johnston location. Time of planting, rating, and harvest at a given location were the same for all plots. 
Plants were allowed to dry in the field prior to harvest. Each hill plot was harvested by placing a bag over the plant panicles and cutting the stems at ground level. Plots were harvested on 6 June 1994 and 4 June 1995 at the Johnston location. Plots were harvested on 8 June 1994 and 9 June 1995 at the Rowan location. The harvested tissue of each hill plot was weighed and recorded and then threshed for seed. The weight of the threshed seed was recorded for each hill plot as yield. Harvest index was determined for each line as the ratio of threshed seed weight to total dry weight of each hill plot as a measure of reduced plant biomass and relative seed production.

Analysis of data was performed using SAS (release 6.10, SAS Institute, Cary, NC; 2). Yield loss was calculated on a percent difference between mean yield of each line in the infested and non-infested treatments at a given location using the formula: (non-infested yield - infested yield)/(non-infested yield) $\times 100$.

Multiple regression analyses were performed with yield loss as the dependent variable and rating, year, and location as independent variables. The maxr and the Mallow's CP functions were used to aid in model development (2). Separate slopes and intercepts were calculated for each cross.

In the analysis of variance, blocks and lines were considered random, with all other variables considered fixed. Years and locations were considered fixed because only two environments were tested for each variable and significant differences were found between years and locations for all dependent variables.

Western blot analysis was performed on leaf tissue collected from border rows of the infested and non-infested plots. Leaf tissue from 10 hill plots was collected each season at the time of greatest foliar symptoms within the experiment, ground in $2 \times$ Laemmli buffer, and centrifuged at 10,000 $\times g$. The supernatant was collected and resolved on a $12.5 \%$ polyacrylamide gel containing sodium dodecyl sulfate. Transfer to nitrocellulose was performed using a Bio-Rad Trans-Blot SD (Bio-Rad Laboratories, Richmond, CA). The membranes were blocked using a $2 \%$ milk solution in Tris-buffered saline. Polyclonal antibodies to OMV and OGSV, developed by Elliott et al. (10), were used as probes. A 1:1,000 dilution of OGSV antisera and a 1:600 dilution of OMV antisera were used, followed by alkaline phosphatase-conjugated secondary antibody (Sigma Chemical Co., St. Louis). Nitroblue tetrazolium chloride and 5-bromo-4-chloro-3-indolyl phosphate were used as alkaline phosphatase substrates.

\section{RESULTS}

Foliar symptoms associated with OMV and OGSV were observed in each location and year. Some hill plots located in the non-infested soil exhibited symptoms of OMV and OGSV infection. However, the disease ratings of these plots did not exceed 1 , and less than $2 \%$ of the total noninfested hill plots exhibited symptoms. The presence of OMV and OGSV were confirmed in the infested treatments at both locations and years by western blot analysis. Western blot analysis was negative for the presence of OMV and OGSV in the border plots of the non-infested treatments in both years. Mean disease ratings for individual lines in the infested treatments ranged from 0.5 to 4 in each population and approximated a normal curve (Fig. 1).

Main effects of year, location, treatment, cross, and lines significantly $(P<0.0001)$ affected disease rating (Table 1). All first-, second-, and third-order interactions also were significant, except those for location $\times$ cross and location $\times$ treatment $\times$ cross. Although year $\times$ cross was significant, disease rating was highest in 1994 for all three crosses (Table 2). The highest overall disease rating occurred in the infested plots at the Rowan location in both years. There

Table 1. Analysis of variance of the effects of environment, crosses, and lines on disease rating, harvest index, and yield of oat lines evaluated for resistance to oat mosaic virus and oat golden stripe virus

\begin{tabular}{|c|c|c|c|c|}
\hline Source & df & $F$ statistic for rating & $\begin{array}{l}F \text { statistic for } \\
\text { harvest index }\end{array}$ & $F$ statistic for yield \\
\hline Year $(Y)$ & 1 & $81.1 * * * \mathrm{z}$ & 0.6 & $64.2 * * *$ \\
\hline Location (L) & 1 & $90.8 * * *$ & $22.3 * *$ & $124.4^{* * *} *$ \\
\hline $\mathrm{Y} \times \mathrm{L}$ & 1 & $61.2 * * *$ & $42.1 * *$ & $14.5^{* *}$ \\
\hline Treatment $(\mathrm{T})$ & 1 & $1976.9 * *$ & $21.2 * *$ & $354.3 * * *$ \\
\hline $\mathrm{Y} \times \mathrm{T}$ & 1 & $79.4 * * *$ & $28.1 * *$ & 0.5 \\
\hline $\mathrm{L} \times \mathrm{T}$ & 1 & $79.8 * * *$ & 0.9 & $32.3 * *$ \\
\hline $\mathrm{Y} \times \mathrm{L} \times \mathrm{T}$ & 1 & $60.3^{* * *}$ & $34.9 * *$ & $10.2^{*}$ \\
\hline Cross (C) & 2 & $55.7 * * *$ & $30.1 * * *$ & $39.4 * * *$ \\
\hline $\mathrm{Y} \times \mathrm{C}$ & 2 & $20.0 * * *$ & $9.7 * *$ & $27.5 * * *$ \\
\hline $\mathrm{L} \times \mathrm{C}$ & 2 & 1.2 & $3.8^{*}$ & $6.9 * *$ \\
\hline $\mathrm{Y} \times \mathrm{L} \times \mathrm{C}$ & 2 & $16.4^{* * *}$ & $21.0 * * *$ & $10.2^{* *}$ \\
\hline $\mathrm{T} \times \mathrm{C}$ & 2 & $58.5^{* * *}$ & $13.3^{* * *}$ & $13.5^{* * *}$ \\
\hline $\mathrm{Y} \times \mathrm{T} \times \mathrm{C}$ & 2 & $21.7 * * *$ & $5.3^{*}$ & $9.7 * *$ \\
\hline $\mathrm{L} \times \mathrm{T} \times \mathrm{C}$ & 2 & 0.7 & $20.5^{* * *}$ & $4.2 *$ \\
\hline $\mathrm{Y} \times \mathrm{L} \times \mathrm{T} \times \mathrm{C}$ & 2 & $15.8 * * *$ & $14.9 * * *$ & $12.8 * * *$ \\
\hline Line $(\mathrm{C})$ & 192 & $2.3 * * *$ & $1.4 * *$ & $3.7 * * *$ \\
\hline
\end{tabular}

$\mathrm{z} *, * *$, and $* * *$ indicate significance at $P<0.05,0.01$, and 0.0001 , respectively.

Table 2. Means ${ }^{\mathrm{x}}$ for ratings of symptoms of oat mosaic virus and oat golden stripe virus, harvest index, and yield ${ }^{y}$ in disease-infested and non-infested soil over 2 years and 2 locations

\begin{tabular}{lccr}
\hline Cross and treatment & Mean rating & Mean harvest index & Mean yield \\
\hline Johnston Co. 1994 & & & \\
Brooks $\times$ C716 In & $1.4 \pm 0.9$ & $41.6 \pm 8.0$ & $25.9 \pm 11.7$ \\
Madison $\times$ C716 In & $1.9 \pm 1.1$ & $41.0 \pm 18.0$ & $16.9 \pm 10.3$ \\
Tech $\times$ C716 In & $2.1 \pm 1.0$ & $41.5 \pm 19.6$ & $21.9 \pm 12.3$ \\
Brooks $\times$ C716 Non & & $33.3 \pm 8.4$ & $29.1 \pm 12.0$ \\
Madison $\times$ C716 Non & & $41.1 \pm 12.5$ & $30.4 \pm 10.9$ \\
Tech $\times$ C716 Non & & $39.8 \pm 10.7$ & $28.4 \pm 11.0$ \\
Rowan Co. 1994 & $3.2 \pm 1.0$ & $47.4 \pm 19.4$ & \\
Brooks $\times$ C716 In & $3.9 \pm 0.3$ & $56.0 \pm 16.5$ & $12.4 \pm 9.4$ \\
Madison $\times$ C716 In & $3.2 \pm 0.9$ & $53.7 \pm 25.4$ & $4.6 \pm 3.0$ \\
Tech $\times$ C716 In & & $43.9 \pm 25.4$ & $8.5 \pm 7.5$ \\
Brooks $\times$ C716 Non & & $49.7 \pm 16.8$ & $39.1 \pm 17.8$ \\
Madison $\times$ C716 Non & $34.2 \pm 16.7$ & $30.0 \pm 16.4$ \\
Tech $\times$ C716 Non & & $23.8 \pm 16.7$ \\
Johnston Co. 1995 & & $47.3 \pm 6.7$ & \\
Brooks $\times$ C716 In & $1.7 \pm 1.3$ & $47.5 \pm 6.3$ & $27.0 \pm 11.4$ \\
Madison $\times$ C716 In & $2.2 \pm 1.3$ & $45.2 \pm 6.7$ & $27.0 \pm 10.3$ \\
Tech $\times$ C716 In & $1.1 \pm 1.2$ & $42.0 \pm 6.1$ & $30.2 \pm 12.6$ \\
Brooks $\times$ C716 Non & & $45.5 \pm 5.5$ & $44.3 \pm 17.3$ \\
Madison $\times$ C716 Non & & $40.3 \pm 4.8$ & $40.5 \pm 15.8$ \\
Tech $\times$ C716 Non & & $42.3 \pm 16.1$ \\
Rowan Co. 1995 & & & \\
Brooks $\times$ C716 In & $1.6 \pm 1.2$ & $40.8 \pm 7.1$ & $13.5 \pm 6.7$ \\
Madison $\times$ C716 In & $2.3 \pm 1.2$ & $40.9 \pm 9.2$ & $11.2 \pm 6.3$ \\
Tech $\times$ C716 In & $1.6 \pm 1.3$ & $41.0 \pm 9.2$ & $15.6 \pm 8.6$ \\
Brooks $\times$ C716 Non & & $46.7 \pm 6.0$ & $32.6 \pm 10.5$ \\
Madison $\times$ C716 Non & & $45.9 \pm 6.1$ & $29.2 \pm 9.0$ \\
Tech $\times$ C716 Non & & $45.2 \pm 5.0$ & $33.6 \pm 10.1$ \\
\hline Mean & & & \\
\hline
\end{tabular}

${ }^{\mathrm{x}}$ Means are calculated as least square values.

y Units for yield and harvest index values are in grams/hill plot.

${ }^{\mathrm{z}}$ Treatments: In $=$ infested soil, Non $=$ non-infested soil. 
were significant differences in mean disease ratings among all crosses grown in the infested treatment at the Johnston location for both years. In contrast, mean ratings for the Tech $\times$ Coker 716 and Brooks $\times$ Coker 716 crosses were not significantly different in the infested treatment at Rowan in either year (Table 2).

Mean harvest index did not differ significantly across years when averaged over locations, treatments, and crosses (Table 1). However, mean harvest index varied significantly among years and locations. Mean harvest index values in the infested treatment were higher than the noninfested treatment for the $\mathrm{F}_{2: 3}$ generation at both the Rowan and Johnston locations, but the means for the $\mathrm{F}_{2: 4}$ generation were significantly higher in the non-infested treatment than in the infested treatment at Rowan in 1995 (Table 2).
Main effects of year, location, treatment, cross, and lines were significant $(P<0.01)$ for yield (Table 1). The year $\times$ treatment interaction for yield was not significant, but all other interaction effects were significant. Yields in the infested treatments were lower than those in non-infested plots for all crosses averaged over years and locations. Mean yield for infested treatments was lower at the Rowan location both years for all crosses.

Mean yield loss for the three crosses ranged from 38.9 to $59.6 \%$ (Table 3 ). The Madison $\times$ Coker 716 population had the highest yield loss for both years, whereas the Tech $\times$ Coker 716 population had the lowest yield loss for both years. The standard deviations were large for all crosses and years. Multiple regression equations were calculated for yield loss for each cross (Table 4). Regression parameter es-

Table 3. Mean percent yield loss due to oat mosaic virus and oat golden stripe virus infection and coefficients of multiple determination $\left(R^{2}\right)$ for the effect of rating, year, and location on yield loss for each cross

\begin{tabular}{lccc}
\hline Cross and year & Percent yield loss & Standard error & $\boldsymbol{R}^{\mathbf{2}}$ \\
\hline Brooks $\times$ C716-1994 & 42.40 & 21.40 & 0.51 \\
Brooks $\times$ C716-1995 & 46.10 & 14.50 & \\
Madison $\times$ C716-1994 & 59.60 & 9.10 & 0.51 \\
Madison $\times$ C716-1995 & 46.80 & 13.60 & \\
Tech $\times$ C716-1994 & 42.00 & 23.80 & 0.39 \\
Tech $\times$ C716-1995 & 38.90 & 18.60 & \\
\hline
\end{tabular}

Table 4. Multiple regression equations relating yield loss to disease rating, year, and location in oat populations from three crosses between parents susceptible and resistant to oat mosaic virus and oat golden stripe virus ${ }^{y}$

\begin{tabular}{|c|c|c|c|c|c|}
\hline \multirow[b]{2}{*}{ Cross $^{\mathrm{z}}$} & \multicolumn{5}{|c|}{ Parameters } \\
\hline & & $b_{0}$ & $b_{1 \text { (rating) }}$ & $b_{2 \text { (year) }}$ & $b_{3 \text { (location) }}$ \\
\hline \multirow{3}{*}{\multicolumn{2}{|c|}{$\begin{array}{l}\mathrm{B} \times \mathrm{C} \\
\mathrm{M} \times \mathrm{C} \\
\mathrm{T} \times \mathrm{C}\end{array}$}} & $3.1 \pm 4.1$ & $11.7 \pm 1.7$ & $12.0 \pm 3.3$ & $24.4 \pm 3.4$ \\
\hline & & $-4.9 \pm 4.8$ & $3.9 \pm 1.8$ & $14.9 \pm 2.5$ & $20.2 \pm 3.7$ \\
\hline & & $33.4 \pm 4.0$ & $5.3 \pm 1.4$ & $-12.4 \pm 2.5$ & $27.4 \pm 2.7$ \\
\hline \multicolumn{6}{|c|}{$\begin{array}{l}\mathrm{y} \text { Years and locations are coded as } 0 \text { and } 1.1994=0,1995=1 ; \text { Johnston Co. }=0 \text {, Rowan Co. }=1 \text {. } \\
{ }^{2} \mathrm{~B} \times \mathrm{C}=\text { Brooks } \times \mathrm{C} 716, \mathrm{M} \times \mathrm{C}=\text { Madison } \times \mathrm{C} 716, \mathrm{~T} \times \mathrm{C}=\mathrm{Tech} \times \mathrm{C} 716 \mathrm{l}\end{array}$} \\
\hline \multicolumn{6}{|c|}{$\begin{array}{l}\text { Table 5. Predicted and observed yield loss (in percent) due to infection by oat mosaic virus and o } \\
\text { golden stripe virus in the Brooks } \times \text { C } 716 \text { population, based on the model presented in Table } 4\end{array}$} \\
\hline Location & Year & Average rating & Predic & Id loss & Observed yield loss \\
\hline Johnston & 1994 & 1.4 & & & 11.0 \\
\hline Rowan & 1994 & 3.2 & & & 68.3 \\
\hline Johnston & 1995 & 1.7 & & & 39.1 \\
\hline Rowan & 1995 & 1.6 & & & 58.6 \\
\hline
\end{tabular}

timates were calculated for rating, year, and location when yield loss is used as the dependent variable (Table 4). Predicted yield loss values were compared to actual yield loss for the Brooks $\times$ Coker 716 population (Table 5). Predicted yield loss is high even at the lowest ratings for all crosses. Year and location effects contributed significantly to differences in yield loss due to disease.

\section{DISCUSSION}

Disease severity varied greatly across years and locations. The disease was most severe at the Rowan location in both years, possibly due to the heavier soil type and cooler climate compared to the Johnston location. The heavier soil type may retain higher levels of moisture and allow for a higher infection frequency. If selection for resistance to OMV and OGSV is restricted to one or a few locations, then locations with heavy soil types and cool temperatures should be used to maximize selection pressure. Testing over a number of years and locations is beneficial, due to large environmental influences on the severity of disease.

Use of foliar symptoms to evaluate resistance to OMV and OGSV is an efficient method, but timing of ratings is critical. In our study, adequate foliar symptoms for visual rating were present only for 14 to 20 days. Our data also indicate the presence of disease tolerance in some oat lines which cannot be detected using foliar symptom data alone (Table 6). Although testing for tolerance in a large number of lines is impractical, it would be advantageous to test lines commonly used as parents.

Based on the data from the multiple regression model, we suggest selecting lines which display foliar symptoms in $10 \%$ or less of the tissue over several rating dates. This may insure low yield loss under severe infections of OMV and OGSV. The model predicts large yield losses for lines with greater than $10 \%$ symptomatic foliar tissue.

Harvest index was a much less reliable method of determining resistance. Problems in using harvest index as a measure of resistance can occur when the parents used to form the population differ in height. Segregation for height will confound har-

Table 6. Examples of tolerant oat lines in which actual yields in infested plots were significantly larger than predicted yields based on significant deviations from regression

\begin{tabular}{lccccc}
\hline Population $^{\mathbf{z}}$ & Line number & Predicted non-infested yield & Actual non-infested yield & Predicted infested yield & Actual infested yield \\
\hline $\mathrm{B} \times \mathrm{C}$ & 2 & 36.9 & 38.4 & 12.6 & 12.9 \\
$\mathrm{~B} \times \mathrm{C}$ & 22 & 38.1 & 42.9 & 24.0 & 18.6 \\
$\mathrm{~B} \times \mathrm{C}$ & 26 & 38.2 & 42.9 & 14.5 & 18.9 \\
$\mathrm{M} \times \mathrm{C}$ & 13 & 32.3 & 32.8 & 13.7 & 29.5 \\
$\mathrm{M} \times \mathrm{C}$ & 40 & 32.7 & 34.8 & 13.8 & 17.5 \\
$\mathrm{M} \times \mathrm{C}$ & 56 & 33.0 & 33.2 & 19.3 & 12.7 \\
$\mathrm{~T} \times \mathrm{C}$ & 1 & 33.2 & 31.9 & 22.4 & \\
$\mathrm{~T} \times \mathrm{C}$ & 44 & 31.9 & 35.1 & 20.0 & 19.7 \\
$\mathrm{~T} \times \mathrm{C}$ & 64 & 31.2 & &
\end{tabular}

${ }^{\mathrm{z}} \mathrm{B} \times \mathrm{C}=$ Brooks $\times \mathrm{C} 716, \mathrm{M} \times \mathrm{C}=$ Madison $\times \mathrm{C} 716, \mathrm{~T} \times \mathrm{C}=\mathrm{Tech} \times \mathrm{C} 716$. 
vest index data in early generation testing of the population. Differences in parental height also prevent comparisons among populations for harvest index. The Madison parent used in this study is considerably shorter than the other parents, and the Madison $\times$ Coker 716 population was significantly different from the other populations for harvest index in both infested and non-infested soil. We recommend using harvest index to evaluate OMV and OGSV resistance only in highly inbred lines, and to make comparisons within but not among populations.

This study demonstrates the need for further study of the effects of OMV and OGSV on yield. Some breeding lines displayed few foliar symptoms but suffered high yield loss due to infection by OMV and OGSV. Conversely, some lines displayed average or severe foliar symptoms but yield loss was reduced (Table 6). Further studies of the disease tolerance component should be undertaken, and methodologies for selection of tolerance could be developed for use in commercial breeding nurseries. Tolerance alone should not be used to increase yield in areas where oats are frequently grown, due to the long-term increase in disease pressure, but should be combined with resistance.

\section{ACKNOWLEDGMENTS}

We thank Lynda Whitcher, Amy Niewoehner, and Ainong Shi for their assistance in the field; and Jack E. Bailey for technical advice.

\section{LITERATURE CITED}

1. Adams, M. J., Jones, P., and Swaby, A. G. 1988. Purification and some properties of oat golden stripe virus. Ann. Appl. Biol. 112:285290.

2. Anonymous. SAS/STAT User's Guide, Vol. 2. SAS Institute Inc., Cary, NC.

3. Atkinson, R. E. 1945. A new mosaic chlorosis of oats in the Carolinas. Plant Dis. Rep. 29:86-89.

4. Bruel, G. W., and Damsteegt, V. D. 1961. Soil-borne mosaic of fall-seeded oats in western Washington. Plant Dis. Rep.45:884888.

5. Byrd, B. W., Graham, D., and Byrd, W. P. 1971. Inheritance of tolerance to soil-borne oat mosaic virus in oats. Crop Sci. 11:875877.

6. Catherall, P. L., and Boulton, R. E. 1979. Reaction of some winter oat cultivars to oat mosaic and oat tubular viruses. Plant Pathol. 28:57-60.

7. Catherall, P. L., and Hayes, J. D. 1970. Oat mosaic virus. Plant Pathol. 19:78-81.

8. Catherall, P. L., and Valentine, J. 1987. Resistances to oat mosaic virus in autumn-sown oats. Ann. Appl. Biol. 111:483-487.

9. Coffman, F. A., Hebert, T. T., Gore, U. R., and Byrd, W. P. 1963. Source and heritability of tolerance to soil-borne mosaic in winter oats. Plant Dis. Rep. 47:54-57.

10. Elliott L. G. 1991. Physicochemical characterization, identification of genetic resistance, and geographic distribution of soilborne oat mosaic in North Carolina. MS thesis. North Carolina State University, Raleigh.

11. Graham, D., Byrd, W. P., and Kingsland, G. C. 1969. Sources of tolerance to soil-borne oat mosaic virus from the world oat collection. Crop Sci. 9:321-322.

12. Hadden, S. J., and Harrison, H. F. 1955. Occurrence of oat mosaic in the lower coastal plain of South Carolina. Plant Dis. Rep. 8:628-630.

13. Hebert, T. T., and Panizo, C. H. 1975. Oat mosaic virus. C.M.I./A.A.B. Page 145 in: Descriptions of Plant Viruses. Wm. Culross \& Son, Ltd., Perthshire, Scotland.

14. Himmel, P. T., Hewings, A. D., and Glawe, D. A. 1991. Incidence of soilborne wheat mosaic virus and its reported vector, Polymyxa graminis, in field-grown soft red winter wheat. Plant Dis. 75:1008-1012.

15. Kendall, T. L., and Lommel, S. A. 1988. Fungus vectored viruses of wheat in Kansas. Pages 37-60 in: Viruses with Fungal Vectors. J. I. Cooper and M. J. C. Asher, eds. Suffolk, UK.

16. Lapierre, H., Courtillot, M., Kusiak, C., and Hariri, D. 1985. Field resistance of autumnsown wheat to wheat soil-borne mosaic virus Agron. Sci. Prod. Veg. Environ. 5:565-572.

17. Linford, M. B., and McKinney, H. H. 1954 Occurrence of Polymyxa graminis in roots of small grains in the United States. Plant Dis. Rep. 10:711-713.

18. MacFarlane, I. 1968. A soil-borne virus of winter oats. Plant Pathol. 17:167-170.

19. McKinney, H. H. 1946. Mosaics of winter oats induced by soil-borne viruses. Phytopathology 36:359-369.

20. McKinney, H. H., Stanton, T. R., Seal, J. L., Rogers, T. H., Paden, W. R., Middleton, G. K., and Gore, U. R. 1949. Mosaics of winter oats and their control in the southeastern states. U. S. Dep. Agric. Circ. 809.

21. Toler, R. W., and Hebert, T. T. 1963. Reaction of oat varieties, Avena species, and other plants to artificial inoculation with the soilborne oat mosaic virus. Plant Dis. Rep. 47:5862.

22. Uhr, D. V., and Murphy, J. P. 1992. Heritability of oat mosaic resistance. Crop Sci. 32:345348. 